\title{
Exacerbations of chronic obstructive pulmonary disease
}

\author{
B.R. Celli* and P.J. Barnes\#
}

ABSTRACT: Exacerbations of chronic obstructive pulmonary disease are of major importance in terms of their prolonged detrimental effects on patients, the acceleration in disease progression and high healthcare costs.

There is still debate about how exacerbations should be defined and graded, and their mechanisms are poorly understood. The major causal agents are either bacteria or viral infections, or a combination of the two. Noninfective causes include air pollution and pulmonary embolus but, in some patients, no cause is identified.

Exacerbations represent an increase in the inflammation that is present in the stable state, with increased numbers of inflammatory cells (particularly neutrophils), cytokines, chemokines and proteases in the airways, and increased concentrations of certain cytokines and C-reactive protein in the blood. There are presently no reliable biomarkers with which to predict exacerbations.

Exacerbations have a long-lasting adverse influence on health status. High doses of bronchodilators are the mainstay of treatment and systemic corticosteroids have some benefit. The routine use of antibiotics remains controversial but they are of benefit with exacerbations of a bacterial origin. Noninvasive ventilation is beneficial in preventing the need for intubation and its important complications but it is not certain whether its use in stable patients prevents exacerbations. Although important advances have been made, more effective treatments are needed in the future for prevention and treatment of exacerbations.

KEYWORDS: Bacterial infection, exacerbation, health status, inflammation, viral infection

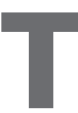
he present review article is a summary of a meeting on the Exacerbations of COPD held in Como, Italy, in April 2005. The meeting was the fourth in the series entitled COPD: the Important Questions. The chairs of the meeting and its participants are listed in the Appendix. The aim of the meeting was to identify important questions related to the exacerbations of chronic obstructive pulmonary disease (COPD) and to discuss future approaches based on recent and evolving research. The present article contains the results of those discussions.

Exacerbations of COPD are of major global importance. They have a profound and longlasting effect on patients, resulting in poor health status; they may accelerate the progression of the disease; and they account for a large proportion of the increasing healthcare spending on COPD. Yet controversies remain over the definition of exacerbations, how they should be monitored and their underlying mechanisms. Exacerbations of COPD are now recognised as important events in the natural course of COPD and this fact is underlined in major international guidelines [1,2]. Exacerbations are an important outcome, not only because they pose a considerable economic burden but more importantly because repeated exacerbations of COPD lead to deteriorating health-related quality of life [3, 4] and, when associated with ventilatory failure, to premature death [5]. There is gathering evidence that exacerbations accelerate the progressive decline in lung function in COPD patients, making their prevention even more important [4]. In general, exacerbation frequency increases with disease severity, as represented by airflow obstruction [6], but the relationship between exacerbation frequency and forced expiratory volume in one second (FEV1) is not particularly close and new evidence indicates a possible role for extrapulmonary factors in the genesis of

\section{AFFILIATIONS}

${ }^{*}$ Caritas St. Elizabeth's Medical Center, Tufts University School of Medicine, Boston, MA, USA.

${ }^{\#}$ National Heart and Lung Institute, Imperial College, London, UK

CORRESPONDENCE

P.J. Barnes

Airway Disease Section

National Heart and Lung Institute

Dovehouse Street

London SW3 6LY

UK

Fax: 442073515675

E-mail: p.j.barnes@imperial.ac.uk

Received:

August 232006

Accepted after revision:

February 152007

STATEMENT OF INTEREST

A statement of interest for this

review can be found at

www.erj.ersjournals.com/misc/

statements.shtml 
exacerbation. Indeed, the BODE index, which includes the body mass index (B), obstruction (O), dyspnoea (D) and exercise endurance measured by the 6-min walk distance $(\mathrm{E})$, is a better predictor of hospitalisation from COPD in a cohort of patients than FEV1 [7].

Over time COPD exacerbations become more frequent and more severe, and this is associated with increasing functional impairment. Thus it is the patients with more severe COPD who are prone to more severe exacerbations and are more likely to need hospital admission, especially in the winter months when respiratory viral infections are common [8]. Risk factors for exacerbation relapses include low pre-treatment FEV1, a need to increase bronchodilator or corticosteroid use, previous exacerbations (more than three in the last $2 \mathrm{yrs}$ ), prior use of antibiotics and the presence of comorbid conditions (congestive heart failure, coronary artery disease, chronic renal or liver failure) [9-12]. Patients with exacerbations are at increased risk of dying compared with patients who do not exacerbate or those who do so but do not require hospital admission [13].

\section{CAUSAL AGENTS}

Bacteria, viruses and environmental agents account for the vast majority of episodes of exacerbation (table 1). In a recent study of patients admitted to hospital with severe exacerbations, $78 \%$ of patients had evidence of viral or bacterial infection (fig. 1) [14]. However, many patients suffer from exacerbations where no specific causes can be identified.

\section{Bacteria}

Several lines of evidence now implicate bacteria as an important cause of exacerbation of COPD $[15,16]$. Bronchoscopic sampling of the distal airways of the lung has demonstrated the presence of pathogenic bacteria in $50 \%$ of exacerbations. Acquisition of new strains of bacterial pathogens has been associated with a more than two-fold increase in the risk of exacerbation [17]. Systemic and mucosal immune responses to nontypeable Haemophilus influenzae, Moraxella catarrhalis and Streptococcus pneumoniae develop in the majority of exacerbations associated with isolation of these bacteria from sputum. Bacterial exacerbations are associated with increased numbers of activated neutrophils in sputum that decline with treatment of the exacerbations using antibiotics [18]. Antibiotic treatment of exacerbations appears to be beneficial, especially in patients with more severe underlying obstructive disease and multisymptom exacerbations [19].

The host-pathogen interaction that determines the consequence of acquisition of strains of bacterial pathogens in a patient with COPD is complex. Increased understanding of this interaction is required to develop an effective means of treatment and prevention of bacterial exacerbations. Pathogen factors that may determine the outcome of the host-pathogen interaction include the ability of bacterial strains to elicit cytokines from and to invade airway epithelial cells. Bacterial colonisation is frequently found in patients with COPD but not in matched normal smokers, and this is associated with an increase in inflammatory markers in induced sputum, suggesting that bacterial colonisation may be a factor increasing airway inflammation [20]. There is an association between bacterial colonisation and increased markers of inflammation in sputum [18] and with the frequency of exacerbations [12].

Host factors that may be important include the development of a mucosal antibody response, as well as cellular immunity to bacterial pathogens. Alterations in innate immunity are likely to be of substantial importance, although these have not been investigated. There is evidence to suggest a defect in macrophage phagocytosis in COPD patients that may result in defective clearance of infectious agents from the lower respiratory tract [21].

Inflammation is recognised as an important pathological feature of COPD and exacerbations are now thought to represent the clinical manifestations of increased inflammation. Little information is available about the patterns of inflammation and spectrum of mediators in exacerbations due to different causal mechanisms.

\section{Viruses}

There is considerable evidence that upper respiratory tract viruses may precipitate exacerbations of COPD. Approximately $50 \%$ of exacerbations are associated with upper respiratory tract virus infections and infection with rhinovirus, respiratory syncytial virus and influenza have been associated with exacerbations [14, 22]. The presence of an upper respiratory

TABLE 1 Causes of chronic obstructive pulmonary disease

\begin{tabular}{lcc} 
Causal mechanism & Common & Less common \\
\hline Bacteria & Haemophilus influenzae & Pseudomonas \\
& Streptococcus pneumoniaie \\
Virus & Moraxella catarrhalis & Rhinovirus \\
& Respiratory syncytial virus & Influenza A and B \\
& Parainfluenza virus & Coronavirus \\
Atypical organisms & Adenovirus \\
Noninfective & Air pollution (particulates, ozone) & Mycoplasma pneumoniae \\
& Cold temperatures & Chlamydia pneumoniae \\
& Pulmonary embolus & Congestive cardiac failure
\end{tabular}




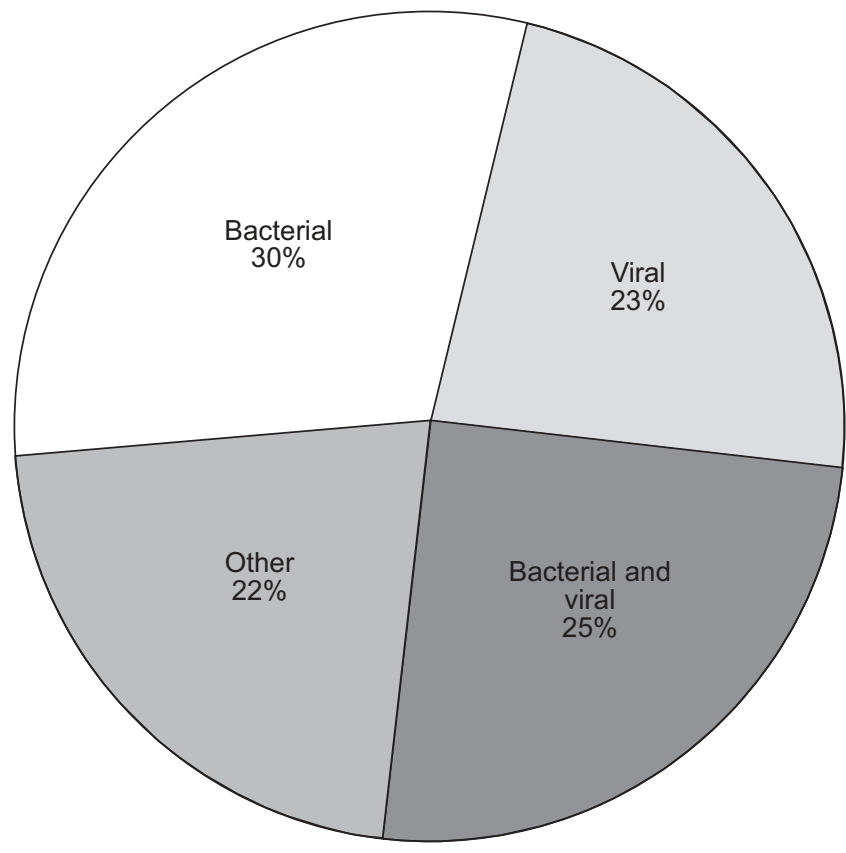

FIGURE 1. Causal mechanisms in chronic obstructive pulmonary disease. Data are derived from [14].

tract infection leads to a more severe exacerbation and a longer symptom recovery time at exacerbation [23]. Increased symptoms induced by virus-associated exacerbations appear to last longer than bacterial exacerbations [8]. More than $60 \%$ of exacerbations in COPD are associated with the symptoms of a common cold [23]. At least one virus is detected by PCR in $64 \%$ of exacerbations of COPD patients and these patients have a higher exacerbation frequency than patients in whom viruses are not detected [8]. COPD patients with a history of frequent exacerbations may be more susceptible to respiratory viral infections, although the nature of this susceptibility has not yet been defined. It is possible that upregulation of the intercellular adhesion molecule-1, which acts as a receptor for rhinoviruses, in airway epithelial cells is important [24] and is upregulated by rhinovirus infection via the activation of the transcription factor, nuclear factor (NF)- $\mathrm{B}$ [25]. Rhinovirus can be recovered from the sputum more easily than from the upper airways, indicating that these viruses directly infect the lower respiratory tract [26, 27]. Virus infections, like bacterial infections, are associated with increased numbers of neutrophils in the sputum, and also with an increase in the numbers of eosinophils, suggesting that different inflammatory mediators are involved [14].

There is increasing recognition that many patients with exacerbations have concomitant viral and bacterial infection. Approximately $25 \%$ of patients admitted to hospital with an exacerbation of COPD had co-infection with bacteria and viruses, and these patients had more severe exacerbations, as measured by length of hospitalisation [14]. In a recent survey, $\sim 70 \%$ of exacerbations were associated with an increase in $H$. influenzae and those patients who had concomitant rhinovirus infection (detected by PCR) had a greater fall in FEV1 and rise in serum interleukin (IL)-6 and sputum CXCL8
(IL-8) [28]. This suggests that patients co-infected with a virus and bacteria may have more severe exacerbations.

\section{Noninfective mechanisms}

Epidemiological studies have shown that hospital admissions with COPD exacerbations increase slightly with a rise in atmospheric levels of sulphur dioxide, ozone, nitrogen dioxide and particulates [29]. There is convincing evidence that exposure to particulates with a 50\% cut-off aerodynamic diameter of $10 \mu \mathrm{m}$ is associated with increased hospital admissions in COPD patients [30]. Particulates induce oxidative stress and, in vitro, this leads to activation of NF- $\kappa \mathrm{B}$, histone acetylation and increased expression of CXCL8 [31]. This is enhanced by adenoviral early region 1A, suggesting that there may be an interaction between virus infection and air pollution in triggering exacerbations [32].

Low temperatures may also be associated with exacerbations of COPD. Reduced temperatures in the bedroom and outside air have been associated with falls in the lung function of COPD patients and an increased frequency of exacerbations [33]. The mechanisms are not yet understood but may relate in part to increased susceptibility to upper respiratory tract virus infections in cold weather. In patients admitted to hospital with severe COPD exacerbations of unknown cause, 25\% had pulmonary embolism confirmed by spiral computerised tomography [34]. Heart failure may also lead to a symptomatic exacerbation of COPD, although it may be difficult to differentiate the symptoms of increased heart failure from those of a COPD exacerbation [35].

\section{MECHANISMS \\ Pathological and cellular changes}

There is an increase in sputum neutrophil numbers in exacerbations of COPD and a recent biopsy study demonstrated an increase in neutrophils in bronchial biopsies, although they are rarely seen in the stable state [36]. In bronchial biopsies of patients with mild exacerbation of chronic bronchitis, an eosinophilia exists that is associated with increased expression of CCL5 (also known as RANTES) [37-39]. Virally induced exacerbations are also associated with increased levels of eosinophils in sputum, as discussed previously [14]. Viral infections induce the expression of CCL5 in airway epithelial cells [40]. CCL5 may act synergistically with CD8+ cells to enhance the apoptosis of virally infected cells, thus leading to increased tissue destruction [41]. There is also an increase in the concentration of the elastolytic enzyme matrix metalloproteinase- 9 and a decrease in its major inhibitor, tissue inhibitor of metalloproteinase-1, in sputum during exacerbations [42]. This is consistent with an increase in urinary desmosine, which is an indicator of elastolysis [43]. This may provide a causal link between exacerbations and accelerated decline in lung function.

\section{Molecular mechanisms}

The cellular and molecular mechanisms of exacerbations are still not well understood but most evidence suggests that they are due to a further amplification of the inflammatory process triggered by bacteria, viruses and noninfective stimuli, such as air pollution (fig. 2). There is a marked increase in neutrophil numbers (accounting for the change in sputum colour) and cytokines that are increased in stable COPD (tumour necrosis 


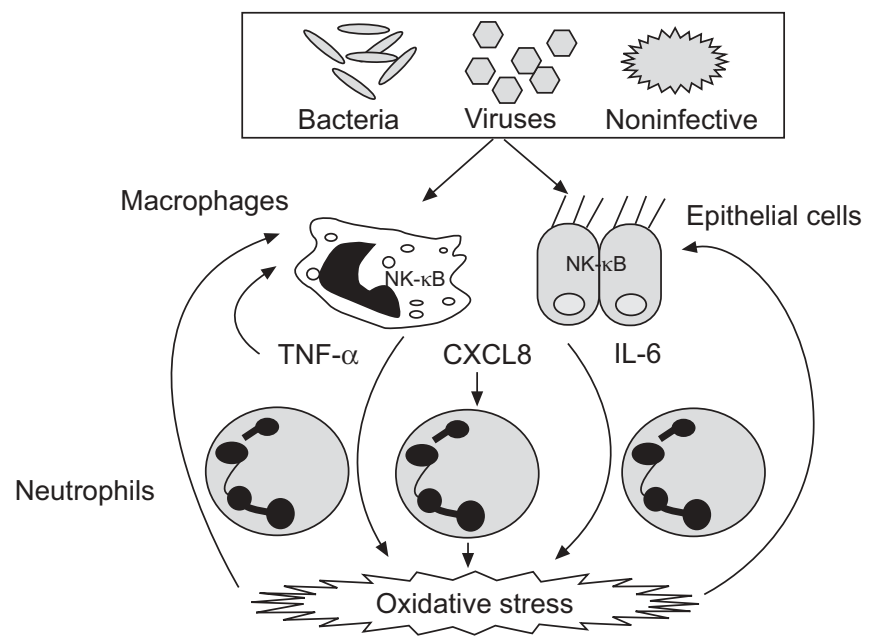

FIGURE 2. Pathogenic mechanisms in chronic obstructive pulmonary disease. Bacteria, viruses and other factors, such as air pollution, may activate the transcription factor nuclear factor (NF)- $\mathrm{kB}$ in airway epithelial cells and macrophages, which then release inflammatory cytokines, including interleukin (IL)-8 (CXCL8), which in turn attracts neutrophils, tumour necrosis factor (TNF)- $\alpha$ and IL-6, both of which amplify inflammation. Increased numbers of neutrophils generate oxidative stress, which further amplifies the inflammatory process.

factor (TNF)- $\alpha$ and IL-8) are further increased during the exacerbation $[44,45]$. There is also increased expression of the chemokine CCL5, which attracts T-cells and eosinophils, and CXCL5 (previously known as epithelial neutrophil-activating peptide (ENA)-78), which attracts neutrophils [36, 46]. IL-6 is increased in sputum, breath and plasma of COPD patients during exacerbations $[8,47,48]$. These mediators are regulated primarily by NF- $\kappa \mathrm{B}$ and there is evidence for its activation in macrophages in COPD exacerbations [49]. Rhinoviruses and bacteria, such as $H$. influenzae, may activate NF- $\mathrm{B}$ through Toll-like receptors (TLR), which recognise surface pathogens (predominantly TLR2, TLR3 and TLR4) [50]. Nontypeable $H$. influenzae activates NF- $\kappa \mathrm{B}$ synergistically with TNF- $\alpha$ through the activating enzyme inhibitor of NF- $\kappa B$ kinase-2 (IKK2) and activation of a p38 mitogen-activated protein kinase (MAPK) pathway [51]. There is an increase in leukotriene (LT) $\mathrm{B}_{4}$ (chemotactic for neutrophils and involved in T-lymphocyte activation) in the sputum and exhaled breath $[52,53]$. Oxidative stress is also increased, as evidenced by an increase in exhaled 8-isoprostane and hydrogen peroxide and this persists over several weeks [53-55]. Nitrative stress may also be increased in exacerbations, as exhaled nitric oxide (NO) levels are higher during exacerbations [56-58]. The increased formation of peroxynitrite may be important in amplifying inflammation during an exacerbation. The prolonged increase in COPD exacerbations may reflect the perpetuation of inflammation through an interaction between oxidative stress and NF- $\kappa \mathrm{B}$ activation, and the establishment of amplification loops. COPD exacerbations respond relatively poorly to corticosteroids indicating a degree of steroid resistance, which may reflect a reduction in histone deacetylase (HDAC)-2 activity in the airways $[59,60]$. The reduction in HDAC in COPD provides a molecular mechanism for amplification of inflammatory gene expression in COPD [61] and may be further reduced by the increased oxidative stress and $\mathrm{NO}$ production during an exacerbation [62]. This may explain why high doses of corticosteroids have relatively low efficacy in the treatment of COPD exacerbations [63].

\section{BIOMARKERS OF EXACERBATIONS}

A biomarker refers to the measurement of any molecule or material (cells and tissue) that reflects the disease process. In COPD, several types of biomarker have been measured that are related to disease pathophysiology and the inflammatory and destructive process in the lung, but there are few measurements during exacerbations [64]. Biomarkers have been measured in blood, urine, sputum, bronchoalveolar lavage and exhaled breath. So far there is little information about whether biomarkers can predict exacerbations or distinguish between different causal mechanisms for exacerbations, thus providing a means of guiding the therapy.

\section{Blood}

Various inflammatory biomarkers, including TNF- $\alpha$, IL- 6 and C-reactive protein (CRP) are increased in the plasma of patients with stable COPD, but it is uncertain whether or not they predict exacerbations. There is an increase in plasma concentrations of inflammatory markers during acute exacerbations, including TNF- $\alpha$ and IL- 6 , and this may represent overspill from the lung $[65,66]$. A recent study measured 36 plasma biomarkers during acute exacerbations in 90 patients with COPD and compared concentrations with the baseline state [67]. The most selective biomarker turned out to be CRP, although it was not specific for an exacerbation. The interrelationships between the various biomarkers suggested that there was an increase in monocyte and lymphocyte activation during an exacerbation. None of the biomarkers proved to be useful in predicting the clinical severity of an exacerbation. Plasma leptin concentrations are increased during an exacerbation and this may indicate negative energy balance during an acute exacerbation [65, 68]. Systemic oxidative stress is also increased during exacerbations, with increased concentrations of markers of oxidative stress and reduced antioxidants [69].

\section{Sputum}

Several inflammatory markers are increased in induced sputum of COPD patients during acute exacerbations and fall during recovery. Increased sputum concentrations of TNF- $\alpha$, IL-6, CXCL8, LTB 4 and endothelin-1 have been reported [45, 47, 70-72]. The increased purulence and colour change of sputum during exacerbations reflects the increased numbers of neutrophils containing the green pigment myeloperoxidase [73]. The colour may be useful in guiding whether antibiotic therapy is likely to be effective [18]

\section{Exhaled NO}

The levels of exhaled NO measured at the mouth are usually normal in patients with COPD [74] but when exhaled NO is partitioned by the multiple flow technique, peripheral $\mathrm{NO}$ (including small airways and lung parenchyma) is increased, whereas bronchial NO is normal [75]. However, exhaled NO is increased during exacerbations of COPD [56-58]. This may reflect increased nitrative stress during exacerbations and this hypothesis is supported by the demonstration of increased 


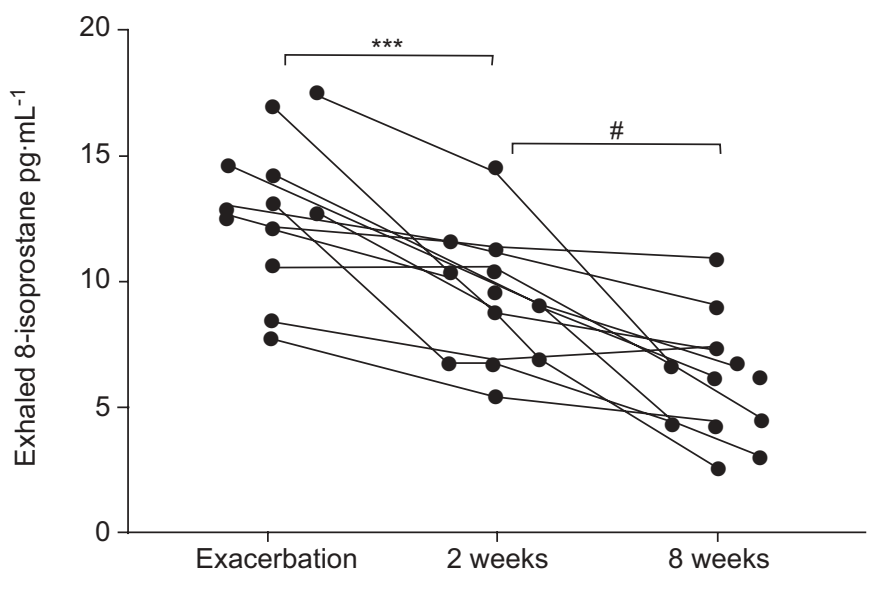

FIGURE 3. Increased oxidative stress in a chronic obstructive pulmonary disease (COPD) exacerbation results in increased 8-isoprostane in exhaled breath condensate of COPD patients treated with antibiotics. 8-Isoprotane concentrations fall to stable levels over 8 weeks. ${ }^{* *}: p<0.001 ;{ }^{*}: p=0.001$.

numbers of nitrotyrosine-positive cells (as a result of increased nitrite and peroxynitrite formation) in induced sputum during an exacerbation compared to the stable state [72].

\section{Exhaled breath condensate}

Several inflammatory mediators and markers of oxidative stress have been measured in exhaled breath condensate. There is a high variability in the measurement and dilution results in very low concentrations of many mediators, making this a difficult measurement [76]. However, this is a noninvasive measurement and is suited to serial measurements during an exacerbation of COPD. An increased concentration of hydrogen peroxide in exhaled breath condensate has been reported during exacerbations of COPD, suggesting increased oxidative stress $[54,55]$. In a general practice-based study, an increase in $\mathrm{LTB}_{4}$ and 8-isoprostane, a marker of oxidative stress, were found in exacerbations of COPD and these abnormalities took several weeks to normalise (fig. 3) [53]. Acute exacerbations of COPD are associated with an increase in several cytokines in exhaled breath condensate, including TNF- $\alpha$, IL-1 $\beta$, IL-6 and CXCL8 [77].

\section{CLINICAL CONSEQUENCE OF EXACERBATIONS Health status}

Although it is recognised that exacerbations are associated with considerable symptomatic and physiological deterioration, the burden imposed on patients may be underestimated. Interestingly, patients are not familiar with the term "exacerbation" as used by healthcare professionals and, if given a choice, they may use their own words to describe the worsening of symptoms. The terminology used by patients is extremely varied but consistent for each patient. The way in which patients perceive exacerbations and how exacerbations affect patients have been greatly helped by the systematic scoring of health status questionnaires. The application of such tools to study exacerbations has provided major new insights, although it still remains a hypothesis-generating exercise. It has been shown that the frequency of exacerbations accounts for some of the differences in health status between patients [3] and for some of the deterioration in health status scores within patients over time [78]. Reducing exacerbation rate appears to reduce this deterioration. The mechanism for this is not clear but is likely to be associated with the large and sustained effect of a single exacerbation on health [78]. Even if the patient fails to improve by a very small degree following each exacerbation, the accumulated effect could account for the progressive deterioration attributable to COPD exacerbations [4]. During an exacerbation, poorer health status is associated with an increased likelihood of further exacerbations within 6 months [78]. Thus, the composite data from patient-centred studies and, mostly, pharmacological trials indicate an important role for repeated exacerbations on the health status of patients with COPD. Furthermore, in one long-term randomised trial comparing inhaled corticosteroids with placebo, there was no significant change in the rate of decline of FEV1 whereas, in the group receiving active medication, there was a slower deterioration in the rate of worsening of the health status scores over time that appeared to be related to a decrease in exacerbation frequency [79].

\section{Physiological consequences}

There is limited information describing the physiological changes that occur during exacerbations of COPD that do not require mechanical ventilation. The data from patients requiring mechanical ventilation indicates the presence of increased central drive, dyspnoea, tachypnoea, reduced tidal volume and development of hypercapnoeic respiratory failure, while ventilation/perfusion matching seems to be relatively preserved [80, 81]. Two recent studies have increased present knowledge about the changes in lung mechanics and its relation to dyspnoea during exacerbation of COPD [82, 83]. In both studies, lung mechanics, including spirometry, inspiratory capacity and dyspnoea, were recorded during recovery from an exacerbation. Consistent reduction in dyspnoea was seen as resolution of the exacerbation. In both studies, the FEV1/forced vital capacity (FVC) ratio and expiratory flow limitation changed relatively little throughout the study period. In contrast, both studies demonstrated that changes in lung volume rather than airflow resistance predominated. During hospitalisation in one of the studies, there was rapid and significant improvement in dyspnoea, respiratory rate, inspiratory capacity, pulse and FVC, and fewer changes in FEV1. The FEV1 and lung volume improved over time. An exacerbation of COPD appears to be characterised by increased central drive, decreased inspiratory capacity and decreased inspiratory muscle force, perhaps secondary to dynamic hyperinflation. Few studies have attempted to relate the changes in physiology to changes in the inflammatory process that are thought to occur during the episodes. There is an association between increased serum levels of IL-6 and LTB $_{4}$ and the magnitude of dyspnoea, respiratory rate and inspiratory capacity [84], suggesting that it may be possible to detect serum changes that reflect the inflammatory burden of the exacerbation. This finding has been confirmed in sputum where changes in concentrations of IL-6, CXCL8, TNF- $\alpha$, myeloperoxidase, neutrophil elastase and $\mathrm{LTB}_{4}$ suggest an inflammatory burst [45, 47, 70]. Once patients develop ventilatory insufficiency, the prognosis is very poor, with $\sim 50 \%$ mortality at 2 yrs [5]. 


\section{Economic consequences}

Some studies have determined that hospitalisation costs represent $40-57 \%$ of total direct costs generated by patients with COPD, and this percentage may be as high as $63 \%$ in severe patients [85]. The average cost of hospitalisation for COPD in a cohort of severe patients was estimated to be $\sim$ US\$7,000. Since acute exacerbations are the main cause of hospitalisation among COPD patients, it is evident that the economic burden of acute exacerbations is considerable. Observational studies performed in primary care centres observed that $16-22 \%$ of patients having exacerbations were admitted during $1 \mathrm{yr}$ [86]. The costs of exacerbations that require hospitalisation increase dramatically compared with those that can be treated in an ambulatory setting. An analysis derived from a clinical trial in patients with COPD demonstrated that the $15 \%$ of exacerbations requiring hospital admission generated $90 \%$ of the costs associated with exacerbations [87]. In a recent study in primary care in Spain, the mean total cost of an acute exacerbation of COPD was estimated to be US\$159, with the main part being due to hospitalisations, which represented $58 \%$ of the total cost, followed by the drug costs amounting to $32 \%$ of the total [88]. However, these costs may not be applicable to other countries because of the differences in reference prices, management practices and healthcare systems. Failure implies a cost that is three times higher than the cost of management of the exacerbation, particularly due to the high cost of hospitalisation. If the percentage of relapses could be reduced, especially in severe cases, or if switching a patient from parenteral to oral therapy could reduce the length of hospital stay, valuable resources could be saved. This is particularly important considering that a recent study demonstrated that patients with stage IV COPD (FEV1 $<35 \%$ predicted) had a significantly greater percentage of failures than successful exacerbations, with $52 \%$ of failures requiring hospitalisation [87]. The costs of managing acute exacerbations of chronic bronchitis are high, particularly because of the high costs associated with relapse $[89,90]$. Strategies to improve the outcome of ambulatory treatment of exacerbations should be very cost-effective, especially in more severe patients who are at increased risk of being admitted to hospital as a consequence of therapeutic failure.

\section{COPD comorbidities and exacerbations}

COPD is a condition that becomes clinically apparent in midto-late life. Comorbidity is relatively common in patients with COPD and this raises the issue as to whether such a comorbidity is age-related, related to a common factor, such as smoking and cardiovascular disease, due to the effect of drugs like corticosteroids and the development of diabetes, or a reflection of the increase in systemic inflammatory cytokine concentrations, which are a feature of COPD with systemic involvement. Data are emerging that the same inflammatory mediators are central to the pathogenesis of other diseases and, to illustrate this, focus was directed towards type 2 diabetes and cardiovascular diseases. Comorbidities are relevant to exacerbations of COPD as there may be an interaction between the comorbid condition and the severity of the exacerbation. For example, exacerbations may worsen heart failure, whereas heart failure may in turn increase the clinical severity of an exacerbation by increasing the degree of dyspnoea.
There is increasing evidence that the cytokines systemically released in COPD, such as CRP, IL- 6 and TNF- $\alpha$, play a key role in the pathogenesis of insulin resistance and type 2 diabetes [91]. Elevated levels of acute-phase proteins and plasminogen activator inhibitor- 1 predict development of type 2 diabetes [92]. Indeed, the odds ratio for developing type 2 diabetes in females with COPD is 1.8 [93]. The mechanism may occur via a common pathway. For example, in COPD, there is a general metabolic shift toward catabolism and an increase in resting energy expenditure [94]. The plasma concentration of TNF- $\alpha$ in patients with COPD and malnutrition is increased [95] and TNF$\alpha$ decreases peripheral insulin action [96]. In addition, oxidative stress is increased in COPD, particularly during exacerbations, and has also been implicated in insulin resistance [97].

\section{Cardiovascular disease}

Recent studies have shown that there is a 3.14 and 2.57 incidence ratio of myocardial infarction or first stroke during the first 3 days after a systemic respiratory infection, suggesting a close association [98]. Systemic respiratory infections are associated with peripheral acute-phase responses, including the production and release of TNF- $\alpha$, IL- 6 and CRP. A subsequent study indicated that the concentrations of IL-6 and CRP in plasma were significantly related to an increased risk of coronary heart disease in males and females, and that an increase in soluble TNF- $\alpha$ receptors was associated with an increased risk in females [99]. Cardiac troponin-1 is often raised during acute exacerbations that require hospitalisation but are without other evidence of an acute coronary syndrome, indicating that an acute exacerbation has detrimental effects on cardiac muscle [100].

Elevation of the CRP is an independent predictor of myocardial infarction. The relative risk for subjects with CRP concentrations $>3 \mathrm{mg} \cdot \mathrm{L}^{-1}$ is 1.79 compared with those in whom the CRP is $<1 \mathrm{mg} \cdot \mathrm{L}^{-1}$ [101]. CRP increases the expression of intercellular adhesion molecules, induces monocyte chemoattractant production, activates complement and mediates low density lipoprotein uptake by macrophages. In addition, CRP may deposit directly into the arterial wall during atherogenesis to create foam cells, which are the building blocks of atherosclerotic plaques. Furthermore, there is an increased pro-thrombotic state in patients with COPD, as shown by increased circulating fibrinogen levels during acute exacerbations [66].

The interaction between comorbidities and COPD is only just beginning to be explored but it is clear that survival in COPD is better predicted by variables other than simply the degree of airflow limitation [102]. How these factors relate to the development and perpetuation of exacerbations remains to be elucidated but they are likely to be very important in patients with COPD.

\section{THERAPY}

\section{Bronchodilators}

Bronchodilators have important roles in both the prevention and treatment of acute exacerbations of COPD. In exacerbations, bronchodilators are the primary treatment modality designed to alleviate patient symptoms, improve physiological state and prevent or reverse respiratory failure. Unlike noninvasive ventilation, the use of bronchodilators has not 
been shown to prolong survival. Nevertheless, several important questions remain about bronchodilators in the setting of acute exacerbations. There is no difference in outcome between nebulised short-acting $\beta_{2}$-agonists and ipratropium bromide in acute exacerbations and no evidence that the combination of these two drugs is any more effective [103]. This contrasts with the greater efficacy of these combinations in stable disease [104]; it is not known whether sequential administration differs from concurrent delivery. Patients admitted for acute exacerbations are usually already taking chronic bronchodilator treatment but there is no convincing evidence for the development of tolerance. The question of how effective rapid-acting bronchodilators are when added to long-acting agents needs to be evaluated in future studies.

Several studies suggest that $\beta$-agonists and anticholinergic bronchodilators can prevent exacerbations [105-109]. These studies show that long-acting agents appear to be more effective than shorter-acting agents in reducing exacerbation frequency [110]. The mechanism by which this benefit is achieved has not yet been fully delineated. It is possible that bronchodilators reduce exacerbation frequency by a common physiological effect through deflating the lungs and reducing dynamic hyperinflation. Why short-acting agents are less effective, however, is not clear, although this may be due to less effective bronchodilatation and fluctuating airway function as the drug effects wear off. An effect mediated through nonbronchodilator mechanisms, such as an anti-inflammatory effect, is also plausible for long-acting $\beta_{2}$-agonists [111] and possibly for tiotropium [112].

\section{Corticosteroids}

The inflammation in COPD is largely resistant to the antiinflammatory effects of corticosteroids and this appears to be due to a reduction in HDAC-2, which is required for corticosteroids to switch off inflammatory genes [62]. However, systemic corticosteroids reduce both systemic inflammation and certain types of airway inflammation. Prednisolone (30 mg for 2 weeks) reduces sputum eosinophil counts by six-fold in patients diagnosed as having COPD but does not have a significant effect on other inflammatory cells [113]. A similar treatment protocol reduces plasma CRP levels by $>60 \%$ in COPD patients [114]. A very high dose of corticosteroids (prednisone $50-75 \mathrm{mg}$ q.d.) reduced plasma CRP by $80 \%$ during an acute exacerbation after $24 \mathrm{~h}$ of therapy and this effect was maintained for a week [115]. Oral corticosteroids have beneficial, albeit small, effects in the management of acute exacerbations. In one trial, prednisolone (30 mg q.d. p.o. for 14 days) shortened the length of hospitalisation by 2 days ( $29 \%$ reduction compared with placebo), improved FEV1 by $60 \mathrm{~mL}$ per day (or 7\% pred overall) and accelerated recovery from symptoms [116]. In another study, systemic corticosteroids improved oxygenation and dyspnoea during acute exacerbations [117]. Treatment with systemic corticosteroids for 2 weeks resulted in higher FEV1 values and lower treatment failures than placebo over 6 months in patients admitted to hospital with COPD exacerbations [118]. Therapy for 8 weeks produced no incremental benefits above those achieved by a 2 -week course. These data are consistent with the observation that $60-80 \%$ of COPD patients recover from their exacerbation by day 15 [23]. The majority of patients with COPD probably only require 2 weeks of oral corticosteroids, but a few with more severe exacerbations may require a longer duration of exposure. Systemic corticosteroids are also useful in preventing hospitalisations and relapses in those who visit emergency departments only during flare-ups. Prednisone (40 mg q.d. p.o. for 10 days) reduced relapses (either an unscheduled physician visit or repeat emergency visit) by $37 \%$ and the risk for hospitalisation by $47 \%$ (although the latter did not reach statistical significance due to insufficient power of the study) [119]. Interestingly, the only subgroup in which prednisone reduced relapses was the group of patients that were also receiving inhaled corticosteroids (relative risk of 0.44 ). In one study, nebulised budesonide ( $2 \mathrm{mg}, 6$ hourly) had a similar clinical effect to oral prednisone $(30 \mathrm{mg}$ q.d.) in the management of more acute exacerbations [120].

One concern about the use of systemic corticosteroids in exacerbations is the possibility of diagnostic confusion with community-acquired pneumonia. However, there is no evidence that systemic corticosteroids worsen health outcomes in community-acquired pneumonia if appropriate antibiotics are used. Indeed, a recent study has suggested that systemic corticosteroids may even reduce morbidity and mortality in community-acquired pneumonia [121]. In summary, there is convincing evidence that systemic corticosteroids improve health outcomes during COPD exacerbations. Their use improves health status, reduces dyspnoea, accelerates recovery of lung function, reduces length of hospitalisations and prevents relapses, which are very common in moderate-tosevere COPD. Whether the addition of inhaled corticosteroids at the time of hospital or emergency department discharge can provide incremental benefits is unknown.

Several recently reported large multicentre trials evaluated the role of inhaled corticosteroids in preventing or slowing the progressive course of symptomatic COPD [79, 122-124]. In all of these trials, while there was no evidence for any reduction in disease progression, exacerbations were reduced by $12-25 \%$ depending on the severity and the definition used. These findings have been confirmed in studies of fixed combination inhalers containing acorticosteroids and a long-acting $\beta_{2^{-}}$ agonist. Both fluticasone/salmeterol and budesonide/formoterol combinations reduce exacerbation frequency to a greater extent than using a corticosteroid or long-acting $\beta_{2}$-agonist alone [125-127]. Retrospective analyses of large databases suggest a possible effect of inhaled corticosteroids on reducing all-cause mortality in COPD patients and, by implication, some effect in reducing exacerbations [128-130]. This prompted the initiation of a large prospective trial to explore the effect of inhaled corticosteroids and a combination inhaler on mortality. Preliminary results of this trial indicate a $17.5 \%$ reduction in death over 3 yrs in patients receiving the fluticasone/salmeterol combination compared with placebo, although this did not quite reach significance $(p=0.52)$ [131]. Patients treated with inhaled fluticasone alone showed no such reduction in mortality. In the same trial, there was a $25 \%$ decrease in moderate-to-severe exacerbations compared with fluticasone/ salmeterol with placebo regardless of the airflow severity. Interestingly, there were more investigator-reported pneumonias in the two arms of treatment with inhaled corticosteroids. This finding deserves further study to establish the nature of the relationship. 


\section{Antibiotics}

The debate about whether or not to give an antibiotic has been driven by studies of the bacteriology of COPD both during and between exacerbations [12, 132-135] and by several placebocontrolled antibiotic trials. The results of these trials are not concordant so there is continuing uncertainty on this topic [136-139]. The recent available data support the prescription of antibiotics in the presence of purulent sputum, although a proportion of the latter will not benefit [140-142]. Specific properties of new antimicrobials, the demonstration of different bacterial isolates in those with different lung function, identification of a subgroup of patients who are more likely to fail with conventional antibiotic therapy and the results of comparative antibiotic studies have been used to support different antibiotic strategies [135, 143, 144]. The guiding principle for the use of antibiotics remain that of knowledge of the local prevalence of bacteria in the population of patients being evaluated, as has been suggested by the American Thoracic Society (ATS)/European Respiratory Society (ERS) and Global Initiative for Chronic Obstructive Lung Disease (GOLD) guidelines [1, 2].

\section{Mechanical ventilation}

Noninvasive or invasive (via endotracheal intubation) mechanical ventilation is a form of life support to be instituted until the cause underlying the acute respiratory failure is reversed with medical therapy [145]. Noninvasive ventilation should be used whenever possible as it has been shown to be an effective treatment for respiratory failure during acute exacerbations of COPD [146, 147]. Indeed, 1-yr mortality is lower in patients receiving noninvasive ventilation for exacerbations of COPD compared with both conventional mechanical ventilation and optimal medical therapy alone [148, 149]. The institution of mechanical ventilation should be considered when, despite optimal medical therapy and oxygen administration, one of the following persists: 1) moderate-to-severe dyspnoea with evident use of accessory muscles and abdominal paradox; 2) moderate-to-severe acidosis $(\mathrm{pH}<7.36)$ and hypercapnia (carbon dioxide arterial tension $\left.\left(\mathrm{Pa}_{1}, \mathrm{CO}_{2}\right)>6-8 \mathrm{kPa}\right)$; and 3) respiratory frequency $>24$ breaths $\cdot \mathrm{min}^{-1}$. Compared with invasive mechanical ventilation, noninvasive ventilation lowers infectious complications and reduces hospitalisation time, resulting in considerable reductions in healthcare costs [150,151]. It is not yet certain whether the use of noninvasive ventilation at home may prevent exacerbations.

\section{FUTURE THERAPIES}

Current pharmacological treatments have a modest effect in treating and preventing exacerbations, indicating the need for new therapies. Since exacerbations, from whatever cause, appear to represent an increase in ongoing inflammation, more effective anti-inflammatory treatments may not only treat exacerbations but may also prevent them, which would be very cost-effective. Several potential anti-inflammatory treatments are now in clinical development [152]. Targeting the causal mechanisms of COPD is a logical approach but it is difficult to differentiate between viral and bacterial infections based on clinical features alone. More rapid diagnostic approaches are therefore needed; for example, the use of PCR to diagnose specific viruses and bacteria in sputum samples, thus allowing more logical treatment. This may then guide the use of appropriate antibiotics and, in the future, antiviral treatments. The future use of biomarkers in the blood or breath to predict the evolution of an exacerbation may allow earlier intervention to prevent the development of a severe exacerbation.

Although several new classes of drug are in development for COPD, there are few clinical trials and little information about whether they prevent exacerbations. Unfortunately, no animal models of COPD exacerbations exist that could be used to explore this in pre-clinical studies and this is an area for future research using acute infections in addition to cigarette smoke exposure. The most clinically advanced new anti-inflammatory treatments are phosphodiesterase (PDE) 4 inhibitors; these have a broad spectrum of anti-inflammatory effects that are relevant to COPD [153] and reduce emphysema in an animal model of COPD [154]. Although the dose of PDE4 inhibitor that can be used is limited by side-effects, such as nausea, vomiting and diarrhoea, PDE4 inhibitors not only improve lung function but also reduce the frequency of exacerbations in COPD patients. One such PDE4 inhibitor, roflumilast $(500 \mathrm{mg}$ q.d.p.o.), was found to significantly decrease the frequency of exacerbations by $34 \%$ over a 6-month period [155]. This effect was largely due to a reduction in mild exacerbations, defined by increased rescue bronchodilator use over 2 days, without any change in the use of oral steroids or hospitalisation. Another study using a different PDE4 inhibitor, cilomilast (15 mg b.i.d.p.o.) showed that a significantly greater percentage of patients were free of exacerbations over a 6-month period in the cilomilast $(74 \%)$ compared with the placebo group $(62 \%)$ [156]. Additional studies are now needed over longer periods of time in more severe patients who have frequent exacerbations.

There is a striking increase in sputum neutrophils during acute exacerbations, suggesting that any drug that inhibits neutrophil recruitment or activation may be of clinical benefit. Chemotactic factors for neutrophils include $\mathrm{LTB}_{4}$ and CXCL8, and the levels of both of these were increased during exacerbations $[45,52]$. Specific $\mathrm{LTB}_{4}$ inhibitors and anti-IL- 8 antibodies reduce the neutrophil chemotactic activity of COPD sputum in the stable state [157]. $\mathrm{LTB}_{4}$ antagonists may therefore be used to prevent and treat exacerbations but no clinical studies have been reported. CXCL8 and related CXC chemokines, including CXCL1 and CXCL5, which are elevated in COPD, act through a common receptor, CXCR2, for which small molecule inhibitors have now been developed [158]. CXCR2 antagonists are currently entering into clinical trials in COPD patients and it is predicted that they may be useful in reducing and treating exacerbations.

Oxidative stress is increased during COPD exacerbations and acts as an amplifying mechanism for inflammation. This suggests that antioxidants may be useful in preventing and treating exacerbations. Although a meta-analysis of clinical studies with $\mathrm{N}$-acetylcysteine, which has antioxidant properties, showed a significant reduction in exacerbation frequency of $\sim 25 \%$ [159], a large placebo-controlled trial did not show any significant reduction in the number of exacerbations [160]. However, when patients not treated with inhaled corticosteroids were analysed, a significant reduction was noted. It is clear that more potent antioxidants are needed in the future. 
Other approaches that are currently being explored are the use of inhibitors of NF- $\mathrm{kB}$ (IKK2 inhibitors) and p38 MAPK inhibitors; both these kinases may mediate the increased inflammation during exacerbations.

\section{TOWARDS A NEW DEFINITION OF EXACERBATIONS}

There is currently no general agreement on the definition of a COPD exacerbation. A standardised definition could provide benefits to patients, physicians, researchers and other healthcare payers (e.g. Primary Care Trusts, insurance companies, etc.) and decision-makers. It would also help patients to optimise their primary and emergency management and would guide physicians in selecting appropriate pharmacological and nonpharmacological therapeutic interventions. An agreed definition would help in the design of randomised clinical trials and allow the results to be accurately evaluated and compared with other trials.

COPD exacerbations have been defined according to the presence of specific signs and symptoms, changes in symptoms and the need for medical intervention, and each of these approaches has positive and negative connotations. Possibly the most seminal definition of COPD exacerbation is the one provided by ANTHONISEN et al. [136], based on the presence of three specific symptoms in a patient with COPD, namely increased shortness of breath, increased sputum volume and increased purulence. Moreover, three subtypes were also proposed (types 1, 2, and 3) according to the occurrence of all or some of the symptoms [136]. In the year 2000, an international panel of chest physicians proposed a second definition: "a sustained worsening of the patient's condition, from the stable state and beyond normal day-to-day variations, that is acute in onset and necessitates a change in treatment in patients with underlying COPD" [161]. Exacerbations were defined in terms of mild, moderate and severe according to the use of healthcare resources. The first definition is essentially symptom based and was designed for the study of the effectiveness of therapies, such as antibiotics. The second definition is "action or event-driven", which dictates a specific medical intervention. Here, instead of specifying particular symptom criteria, the definition includes a deterioration of respiratory symptoms that requires the use of systemic corticosteroids either with or without antibiotics and/or hospitalisation due to symptoms. These action-driven definitions may vary among regions and countries, and are heavily dependent on the local availability of healthcare. In addition, they are of little value to the clinician seeing an individual patient.

It may be time to learn from the advances provided by the cumulative experience seen in the evaluation and classification of the natural history of coronary artery disease; a parallel approach is summarised in table 2. Coronary artery disease is similar to COPD in that it has a long asymptomatic phase where preventive therapy is highly effective. Once detected, the disease may be stable and treated as such. In patients with COPD, at a certain point in time the disease may become more symptomatic and unstable; this clinical syndrome could be named "unstable COPD" akin to the similar picture in the patient with coronary artery disease where the diagnosis of "unstable angina" prompts modifications in therapy and more careful follow-up. If the decompensation is associated with refractory dyspnoea ( $>4$ on a 0-10 scale), worse cough and sputum, manifestations of systemic involvement, such as tachypnoea $\left(>24\right.$ breaths $\left.\cdot \mathrm{min}^{-1}\right)$, fever, elevated white cell count $\left(>9,000\right.$ cells $\left.\cdot \mathrm{dL}^{-1}\right)$ and $\mathrm{CRP}\left(>10 \mathrm{mg} \cdot \mathrm{dL}^{-1}\right)$, without evidence of

TABLE 2 Proposed clinical definitions of chronic obstructive pulmonary disease (COPD) syndromes by analogy to syndromes in
coronary artery disease

\begin{tabular}{|c|c|}
\hline \multicolumn{2}{|l|}{ COPD } \\
\hline \multirow[t]{4}{*}{ Unstable COPD } & Worsening of dyspnoea cough or sputum \\
\hline & $\mathrm{RR}<24$ \\
\hline & Dyspnoea $<4$ on $0-10$ scale \\
\hline & Normal laboratory investigations \\
\hline \multirow[t]{4}{*}{ Exacerbation } & Worsening of dyspnoea, cough or sputum \\
\hline & Dyspnoea $\geqslant 4$ on a $0-10$ scale \\
\hline & Normal chest radiograph \\
\hline & WBC count $>9000$ cells $\cdot \mathrm{dL}^{-1}$ or $\mathrm{CRP}>10 \mathrm{mg} \cdot \mathrm{dL}^{-1}$ \\
\hline Ventilatory insufficiency & Same plus elevation of $\mathrm{Pa}_{1} \mathrm{CO}_{2}$ in arterial blood gases \\
\hline \multicolumn{2}{|l|}{ Coronary artery disease } \\
\hline \multirow[t]{3}{*}{ Unstable angina } & Worsening of chest pain \\
\hline & No ECG changes \\
\hline & Normal laboratory results \\
\hline \multirow[t]{3}{*}{ Myocardial infarction } & Chest pain \\
\hline & Abnormal ECG \\
\hline & Abnormal serum enzyme pattern \\
\hline Cardiogenic shock & Same syndrome plus shock \\
\hline
\end{tabular}

RR: relative risk; WBC: white blood cell; CRP: C-reactive protein; $\mathrm{Pa}, \mathrm{CO}_{2}$ : carbon dioxide arterial tension. 
infiltrates in the chest radiograph, the syndrome could be defined as "exacerbation" or "chest attack", akin to the myocardial infarction or "heart attack" of coronary artery disease. Finally, if the same syndrome is accompanied by hypoxaemia and elevation of $\mathrm{Pa}_{1} \mathrm{CO}_{2}$ in the arterial blood, the syndrome is defined as "ventilatory failure", akin to the cardiogenic shock in coronary artery disease. These definitions have the advantage of being practical and of providing clear guidance to clinicians, and would also help to classify the episodes, thus providing a valuable tool to prospectively evaluate the effect of therapy on either the episode itself or its prevention.

\section{CONCLUSIONS}

Exacerbations of chronic obstructive pulmonary disease have rightly become an important outcome to define, prevent and treat during the natural course of the disease in patients. The present article has reviewed recent advances in the causes, mechanisms and pathophysiological and clinical consequences of exacerbations. Evidence has also been presented that supports the use of pharmacological and nonpharmacological therapies in the prevention and treatment of the exacerbations per se. Central to the development of exacerbation is the role of inflammation and, as such, the potential development of new anti-inflammatory therapy is also reviewed. Finally, a new definition and classification is proposed as a way to add objective elements to the now-subjective definition of exacerbations of chronic obstructive pulmonary disease. It is hoped that current and future research will result in an even more significant impact on exacerbations of chronic obstructive pulmonary disease.

\section{APPENDIX}

The meeting summarised in the present review was chaired by P. Barnes (National Heart and Lung Institute, Imperial College, London, UK) and B. Celli (Caritas St. Elizabeth's Medical Center, Tufts University School of Medicine, Boston, MA, USA). The following people also participated in the meeting: $\mathrm{P}$. Calverley (University Hospital Aintree, Liverpool, UK), M. Elliot (St James's University Hospital, Leeds, UK), S. Johnston (National Heart and Lung Institute), T. Hansel (Royal Brompton Hospital, London, UK), P. Jones (University of London, London, UK), S. Kharitonov (National Heart and Lung Institute), W. MacNee (The Queen's Medical Research Institute, Edinburgh, UK), R. Stockley (The Queen Elisabeth Hospital, Birmingham, UK), W. Wedzicha (Royal Free Hospital, London, UK), M. Woodhead (Manchester Royal Infirmary, Manchester, UK), A. Young (AstraZeneca, Charnwood, UK), T. Larsson (AstraZeneca, Lund, Sweden), M. Miravitlles (Servicio de Neumologia, UVIR, Barcelona, Spain), J. Roca (Hospital Clinic, Villarroel, Barcelona, Spain), R. Rodriguez Roisin (Hospital Clinic, Barcelona, Spain), D. Niewoehner (University of Minnesota, Minneapolis, MN, USA), S. Rennard (University of Nebraska Medical Centre, Nebraska Medical Centre, Omaha, NE, USA), S. Sethi (University of Buffalo, Buffalo, NY, USA), M. Saetta (Universite degli Studi di padova, Padova, Italy), D. Sin (University of British Colombia, Vancouver, BC, Canada). E. Stahl (IVAX Research Institute, Pulmonary Clinic of Research, Miami, FL, Sweden).

\section{REFERENCES}

1 Global Initiative for Chronic Obstructive Lung Disease (GOLD). Global strategy for the diagnosis, management of chronic obstructive pulmonary disease. NHLBI/WHO Workshop Report 2006. www.goldcopd.com/workshop/ index.html. Date last updated: November 2006. Date last accessed: February 2007.

2 Celli BR, Macnee W. Standards for the diagnosis and treatment of patients with COPD: a summary of the ATS/ERS position paper. Eur Respir J 2004; 23: 932-946.

3 Seemungal TA, Donaldson GC, Paul EA, Bestall JC, Jeffries DJ, Wedzicha JA. Effect of exacerbation on quality of life in patients with chronic obstructive pulmonary disease. Am J Respir Crit Care Med 1998; 157: 1418-1422.

4 Donaldson GC, Seemungal TA, Bhowmik A, Wedzicha JA. Relationship between exacerbation frequency and lung function decline in chronic obstructive pulmonary disease. Thorax 2002; 57: 847-852.

5 Connors AF Jr, Dawson NV, Thomas C, et al. Outcomes following acute exacerbation of severe chronic obstructive lung disease. The SUPPORT investigators (Study to Understand Prognoses and Preferences for Outcomes and Risks of Treatments). Am J Respir Crit Care Med 1996; 154: 959-967.

6 Dewan NA, Rafique S, Kanwar B, et al. Acute exacerbation of COPD: factors associated with poor treatment outcome. Chest 2000; 117: 662-671.

7 Ong KC, Earnest A, Lu SJ. A multidimensional grading system (BODE index) as predictor of hospitalization for COPD. Chest 2005; 128: 3810-3816.

8 Seemungal T, Harper-Owen R, Bhowmik A, et al. Respiratory viruses, symptoms, and inflammatory markers in acute exacerbations and stable chronic obstructive pulmonary disease. Am J Respir Crit Care Med 2001; 164: 1618-1623.

9 Garcia-Aymerich J, Monso E, Marrades RM, et al. Risk factors for hospitalization for a chronic obstructive pulmonary disease exacerbation. EFRAM study. Am J Respir Crit Care Med 2001; 164: 1002-1007.

10 Miravitlles M, Guerrero T, Mayordomo C, SanchezAgudo L, Nicolau F, Segu JL. Factors associated with increased risk of exacerbation and hospital admission in a cohort of ambulatory COPD patients: a multiple logistic regression analysis. The EOLO Study Group. Respiration 2000; 67: 495-501.

11 Yohannes AM, Baldwin RC, Connolly MJ. Depression and anxiety in elderly patients with chronic obstructive pulmonary disease. Age Ageing 2006; 35: 457-459.

12 Patel IS, Seemungal TA, Wilks M, Lloyd-Owen SJ, Donaldson GC, Wedzicha JA. Relationship between bacterial colonisation and the frequency, character, and severity of COPD exacerbations. Thorax 2002; 57: 759-764.

13 Soler-Cataluna JJ, Martinez-Garcia MA, Roman SP, Salcedo E, Navarro M, Ochando R. Severe acute exacerbations and mortality in patients with chronic obstructive pulmonary disease. Thorax 2005; 60: 925-931.

14 Papi A, Bellettato CM, Braccioni F, et al. Infections and airway inflammation in chronic obstructive pulmonary disease severe exacerbations. Am J Respir Crit Care Med 2006; 173: 1114-1121. 
15 Sethi S, Muscarella K, Evans N, Klingman KL, Grant BJ, Murphy TF. Airway inflammation and etiology of acute exacerbations of chronic bronchitis. Chest 2000; 118: 1557-1565.

16 Murphy TF. The role of bacteria in airway inflammation in exacerbations of chronic obstructive pulmonary disease. Curr Opin Infect Dis 2006; 19: 225-230.

17 Sethi S, Evans N, Grant BJ, Murphy TF. New strains of bacteria and exacerbations of chronic obstructive pulmonary disease. N Engl J Med 2002; 347: 465-471.

18 Hill AT, Campbell EJ, Hill SL, Bayley DL, Stockley RA. Association between airway bacterial load and markers of airway inflammation in patients with stable chronic bronchitis. Am J Med 2000; 109: 288-295.

19 Sethi S, Anzueto A, Farrell DJ. Antibiotic activity of telithromycin and comparators against bacterial pathogens isolated from 3,043 patients with acute exacerbation of chronic bronchitis. Ann Clin Microbiol Antimicrob 2005; 4: 5.

20 Sethi S, Maloney J, Grove L, Wrona C, Berenson CS. Airway inflammation and bronchial bacterial colonization in chronic obstructive pulmonary disease. Am J Respir Crit Care Med 2006; 173: 991-998.

21 Hodge S, Hodge G, Scicchitano R, Reynolds PN, Holmes M. Alveolar macrophages from subjects with chronic obstructive pulmonary disease are deficient in their ability to phagocytose apoptotic airway epithelial cells. Immunol Cell Biol 2003; 81: 289-296.

22 Wedzicha JA. Role of viruses in exacerbations of chronic obstructive pulmonary disease. Proc Am Thorac Soc 2004; 1: 115-120.

23 Seemungal TA, Donaldson GC, Bhowmik A, Jeffries DJ, Wedzicha JA. Time course and recovery of exacerbations in patients with chronic obstructive pulmonary disease. Am J Respir Crit Care Med 2000; 161: 1608-1613.

24 Patel IS, Roberts NJ, Lloyd-Owen SJ, Sapsford RJ, Wedzicha JA. Airway epithelial inflammatory responses and clinical parameters in COPD. Eur Respir J 2003; 22: 94-99.

25 Papi A, Johnston SL. Rhinovirus infection induces expression of its own receptor intercellular adhesion molecule 1 (ICAM-1) via increased NF-kappaB-mediated transcription. J Biol Chem 1999; 274: 9707-9720.

26 Seemungal T, Harper-Owen R, Bhowmik A, Jeffries DJ, Wedzicha JA. Detection of rhinoviruses in induced sputum at exacerbations of chronic obstructive pulmonary disease. Eur Respir J 2000; 16: 677-683.

27 Rohde G, Wiethege A, Borg I, et al. Respiratory viruses in exacerbations of chronic obstructive pulmonary disease requiring hospitalisation: a case-control study. Thorax 2003; 58: 37-42.

28 Wilkinson TM, Hurst JR, Perera WR, Wilks M, Donaldson GC, Wedzicha JA. Effect of interactions between lower airway bacterial and rhinoviral infection in exacerbations of COPD. Chest 2006; 129: 317-324.

29 Anderson HR, Spix C, Medina S, et al. Air pollution and daily admissions for chronic obstructive pulmonary disease in 6 European cities: results from the APHEA project. Eur Respir J 1997; 10: 1064-1071.

30 Wordley J, Walters S, Ayres JG. Short term variations in hospital admissions and mortality and particulate air pollution. Occup Environ Med 1997; 54: 108-116.
31 Gilmour PS, Rahman I, Donaldson K, Macnee W. Histone acetylation regulates epithelial IL-8 release mediated by oxidative stress from environmental particles. Am J Physiol Lung Cell Mol Physiol 2003; 284: L533-L540.

32 Gilmour PS, Rahman I, Hayashi S, Hogg JC, Donaldson K, Macnee W. Adenoviral E1A primes alveolar epithelial cells to PM(10)-induced transcription of interleukin-8. Am J Physiol Lung Cell Mol Physiol 2001; 281: L598-L606.

33 Donaldson GC, Seemungal T, Jeffries DJ, Wedzicha JA. Effect of temperature on lung function and symptoms in chronic obstructive pulmonary disease. Eur Respir J 1999; 13: 844-849.

34 Tillie-Leblond I, Marquette CH, Perez T, et al. Pulmonary embolism in patients with unexplained exacerbation of chronic obstructive pulmonary disease: prevalence and risk factors. Ann Intern Med 2006; 144: 390-396.

35 Rutten FH, Cramer MJ, Lammers JW, Grobbee DE, Hoes AW. Heart failure and chronic obstructive pulmonary disease: an ignored combination? Eur J Heart Fail 2006; 8: 706-711.

36 Qiu Y, Zhu J, Bandi V, et al. Biopsy neutrophilia, chemokine and receptor gene expression in severe exacerbations of COPD. Am J Respir Crit Care Med 2003; 168: 968-975.

37 Saetta M, Distefano A, Maestrelli P, et al. Airway eosinophilia in chronic bronchitis during exacerbations. Am J Respir Crit Care Med 1994; 150: 1646-1652.

38 Fujimoto K, Yasuo M, Urushibata K, Hanaoka M, Koizumi T, Kubo K. Airway inflammation during stable and acutely exacerbated chronic obstructive pulmonary disease. Eur Respir J 2005; 25: 640-646.

39 Zhu J, Qiu YS, Majumdar S, et al. Exacerbations of bronchitis: bronchial eosinophilia and gene expression for interleukin-4, interleukin-5, and eosinophil chemoattractants. Am J Respir Crit Care Med 2001; 164: 109-116.

40 Gern JE, French DA, Grindle KA, BrockmanSchneider RA, Konno S, Busse WW. Double-stranded RNA induces the synthesis of specific chemokines by bronchial epithelial cells. Am J Respir Cell Mol Biol 2003; 28: 731-737.

41 Hadida F, Vieillard V, Mollet L, Clark-Lewis I, Baggiolini M, Debre P. Cutting edge: RANTES regulates Fas ligand expression and killing by HIV-specific CD8 cytotoxic T cells. J Immunol 1999; 163: 1105-1109.

42 Mercer PF, Shute JK, Bhowmik A, Donaldson GC, Wedzicha JA, Warner JA. MMP-9, TIMP-1 and inflammatory cells in sputum from COPD patients during exacerbation. Respir Res 2005; 6: 151.

43 Fiorenza D, Viglio S, Lupi A, et al. Urinary desmosine excretion in acute exacerbations of COPD: a preliminary report. Respir Med 2002; 96: 110-114.

44 Hill AT, Bayley D, Stockley RA. The interrelationship of sputum inflammatory markers in patients with chronic bronchitis. Am J Respir Crit Care Med 1999; 160: 893-898.

45 Aaron SD, Angel JB, Lunau M, et al. Granulocyte inflammatory markers and airway infection during acute exacerbation of chronic obstructive pulmonary disease. Am J Respir Crit Care Med 2001; 163: 349-355.

46 Zhu J, Majumdar S, Qiu Y, et al. Interleukin-4 and interleukin-5 gene expression and inflammation in the mucus-secreting glands and subepithelial tissue of smokers with chronic bronchitis. Lack of relationship 
with CD8(+) cells. Am J Respir Crit Care Med 2001; 164: 2220-2228.

47 Bhowmik A, Seemungal TA, Sapsford RJ, Wedzicha JA. Relation of sputum inflammatory markers to symptoms and lung function changes in COPD exacerbations. Thorax 2000; 55: 114-120.

48 Carpagnano GE, Resta O, Foschino-Barbaro MP, et al. Exhaled interleukine-6 and 8-isoprostane in chronic obstructive pulmonary disease: effect of carbocysteine lysine salt monohydrate (SCMC-Lys). Eur J Pharmacol 2004; 505: 169-175.

49 Caramori G, Romagnoli M, Casolari P, et al. Nuclear localisation of p65 in sputum macrophages but not in sputum neutrophils during COPD exacerbations. Thorax 2003; 58: 348-351.

50 Chaudhuri N, Dower SK, Whyte MK, Sabroe I. Toll-like receptors and chronic lung disease. Clin Sci (Lond) 2005; 109: 125-133.

51 Watanabe T, Jono H, Han J, Lim DJ, Li JD. Synergistic activation of NF-кB by nontypeable Haemophilus influenzae and tumor necrosis factor a. Proc Natl Acad Sci USA 2004; 101: 3563-3568.

52 Crooks SW, Bayley DL, Hill SL, Stockley RA. Bronchial inflammation in acute bacterial exacerbations of chronic bronchitis: the role of leukotriene B4. Eur Respir J 2000; 15: 274-280.

53 Biernacki WA, Kharitonov SA, Barnes PJ. Increased leukotriene B4 and 8-isoprostane in exhaled breath condensate of patients with exacerbations of COPD. Thorax 2003; 58: 294-298.

54 Dekhuijzen PNR, Aben KHH, Dekker I, et al. Increased exhalation of hydrogen peroxide in patients with stable and unstable chronic obstructive pulmonary disease. Am J Respir Crit Care Med 1996; 154: 813-816.

55 Gerritsen WB, Asin J, Zanen P, van den Bosch JM, Haas FJ. Markers of inflammation and oxidative stress in exacerbated chronic obstructive pulmonary disease patients. Respir Med 2005; 99: 84-90.

56 Maziak W, Loukides S, Culpitt S, Sullivan P, Kharitonov SA, Barnes PJ. Exhaled nitric oxide in chronic obstructive pulmonary disease. Am J Respir Crit Care Med 1998; 157: 998-1002.

57 Agusti AG, Villaverde JM, Togores B, Bosch M. Serial measurements of exhaled nitric oxide during exacerbations of chronic obstructive pulmonary disease. Eur Respir J 1999; 14: 523-528.

58 Bhowmik A, Seemungal TA, Donaldson GC, Wedzicha JA. Effects of exacerbations and seasonality on exhaled nitric oxide in COPD. Eur Respir J 2005; 26: 1009-1015.

59 Barnes PJ, Ito K, Adcock IM. A mechanism of corticosteroid resistance in COPD: inactivation of histone deacetylase. Lancet 2004; 363: 731-733.

60 Barnes PJ, Adcock IM, Ito K. Histone acetylation and deacetylation: importance in inflammatory lung diseases. Eur Respir J 2005; 25: 552-563.

61 Ito $\mathrm{K}$, Ito $\mathrm{M}$, Elliott WM, et al. Decreased histone deacetylase activity in chronic obstructive pulmonary disease. N Engl J Med 2005; 352: 1967-1976.

62 Barnes PJ. Reduced histone deacetylase in COPD: clinical implications. Chest 2006; 129: 151-155.
63 Niewoehner DE. The role of systemic corticosteroids in acute exacerbation of chronic obstructive pulmonary disease. Am J Respir Med 2002; 1: 243-248.

64 Barnes PJ, Chowdhury B, Kharitonov SA, et al. Pulmonary biomarkers in chronic obstructive pulmonary disease. Am J Respir Crit Care Med 2006; 174: 6-14.

65 Calikoglu M, Sahin G, Unlu A, et al. Leptin and TNFalpha levels in patients with chronic obstructive pulmonary disease and their relationship to nutritional parameters. Respiration 2004; 71: 45-50.

66 Wedzicha JA, Seemungal TA, MacCallum PK, et al. Acute exacerbations of chronic obstructive pulmonary disease are accompanied by elevations of plasma fibrinogen and serum IL-6 levels. Thromb Haemost 2000; 84: 210-215.

67 Hurst JR, Donaldson GC, Perera WR, et al. Use of plasma biomarkers at exacerbation of chronic obstructive pulmonary disease. Am J Respir Crit Care Med 2006; 174: 867-874.

68 Creutzberg EC, Wouters EF, Vanderhoven-Augustin IM, Dentener MA, Schols AM. Disturbances in leptin metabolism are related to energy imbalance during acute exacerbations of chronic obstructive pulmonary disease. Am I Respir Crit Care Med 2000; 162: 1239-1245.

69 Rahman I, Skwarska E, Macnee W. Attenuation of oxidant/antioxidant imbalance during treatment of exacerbations of chronic obstructive pulmonary disease. Thorax 1997; 52: 565-568.

70 Gompertz S, O’Brien C, Bayley DL, Hill SL, Stockley RA. Changes in bronchial inflammation during acute exacerbations of chronic bronchitis. Eur Respir J 2001; 17: 1112-1119.

71 Roland M, Bhowmik A, Sapsford RJ, et al. Sputum and plasma endothelin-1 levels in exacerbations of chronic obstructive pulmonary disease. Thorax 2001; 56: 30-35.

72 Tsoumakidou M, Tzanakis N, Chrysofakis G, Siafakas NM. Nitrosative stress, heme oxygenase- 1 expression and airway inflammation during severe exacerbations of COPD. Chest 2005; 127: 1911-1918.

73 Stockley RA, Bayley D, Hill SL, Hill AT, Crooks S, Campbell EJ. Assessment of airway neutrophils by sputum colour: correlation with airways inflammation. Thorax 2001; 56: 366-372.

74 Kharitonov SA, Barnes PJ. Exhaled markers of pulmonary disease. Am J Respir Crit Care Med 2001; 163: 1693-1772.

75 Brindicci C, Ito K, Resta O, Pride NB, Barnes PJ, Kharitonov SA. Exhaled nitric oxide from lung periphery is increased in COPD. Eur Respir J 2005; 26: 52-59.

76 Horvath I, Hunt J, Barnes PJ. Exhaled breath condensate: report of ERS/ATS Task Force: methodological recommendations and unresolved questions. Eur Respir J 2005; 26: 523-548.

77 Gessner C, Scheibe R, Wotzel M, et al. Exhaled breath condensate cytokine patterns in chronic obstructive pulmonary disease. Respir Med 2005; 99: 1229-1240.

78 Spencer S, Calverley PM, Burge PS, Jones PW. Impact of preventing exacerbations on deterioration of health status in COPD. Eur Respir J 2004; 23: 698-702.

79 Burge PS, Calverley PMA, Jones PW, Spencer S, Anderson JA, Maslen T. Randomised, double-blind, placebo-controlled study of fluticasone propionate in patients with moderate to severe chronic obstructive pulmonary disease; the ISOLDE trial. BMJ 2000; 320: 1297-1303. 
80 Diaz O, Iglesia R, Ferrer M, et al. Effects of noninvasive ventilation on pulmonary gas exchange and hemodynamics during acute hypercapnic exacerbations of chronic obstructive pulmonary disease. Am J Respir Crit Care Med 1997; 156: 1840-1845.

81 Confalonieri M, Garuti G, Cattaruzza MS, et al. A chart of failure risk for noninvasive ventilation in patients with COPD exacerbation. Eur Respir J 2005; 25: 348-355.

82 Stevenson NJ, Walker PP, Costello RW, Calverley PM. Lung mechanics and dyspnea during exacerbations of chronic obstructive pulmonary disease. Am J Respir Crit Care Med 2005; 172: 1510-1516.

83 Parker CM, Voduc N, Aaron SD, Webb KA, O'Donnell DE. Physiological changes during symptom recovery from moderate exacerbations of COPD. Eur Respir J 2005; 26: 420-428.

84 Pinto-Plata V, Livnat G, Girish M, et al. Systemic cytokines, clinical and physiological changes in patients hospitalized for COPD exacerbation. Chest 2006; 131: 37-43.

85 Hilleman DE, Dewan N, Malesker M, Friedman M. Pharmacoeconomic evaluation of COPD. Chest 2000; 118: 1278-1285.

86 Pena VS, Miravitlles M, Gabriel R, et al. Geographic variations in prevalence and underdiagnosis of COPD: results of the IBERPOC multicentre epidemiological study. Chest 2000; 118: 981-989.

87 Miravitlles M, Murio C, Guerrero T, Gisbert R. Pharmacoeconomic evaluation of acute exacerbations of chronic bronchitis and COPD. Chest 2002; 121: 1449-1455.

88 Miravitlles M, Ferrer M, Pont A, et al. Characteristics of a population of COPD patients identified from a population-based study. Focus on previous diagnosis and never smokers. Respir Med 2005; 99: 985-995.

89 Feenstra TL, van Genugten ML, Hoogenveen RT, Wouters EF, Rutten-van Molken MP. The impact of aging and smoking on the future burden of chronic obstructive pulmonary disease: a model analysis in the Netherlands. Am J Respir Crit Care Med 2001; 164: 590-596.

90 Jacobson L, Hertzman P, Lofdahl CG, Skoogh BE, Lindgren $\mathrm{B}$. The economic impact of asthma and chronic obstructive pulmonary disease (COPD) in Sweden in 1980 and 1991. Respir Med 2000; 94: 247-255.

91 Festa A, D’Agostino R Jr, Howard G, Mykkanen L, Tracy RP, Haffner SM. Chronic subclinical inflammation as part of the insulin resistance syndrome: the Insulin Resistance Atherosclerosis Study (IRAS). Circulation 2000; 102: 42-47.

92 Festa A, D'Agostino R Jr, Tracy RP, Haffner SM. Elevated levels of acute-phase proteins and plasminogen activator inhibitor-1 predict the development of type 2 diabetes: the insulin resistance atherosclerosis study. Diabetes 2002; 51: 1131-1137.

93 Rana JS, Mittleman MA, Sheikh J, et al. Chronic obstructive pulmonary disease, asthma, and risk of type 2 diabetes in women. Diabetes Care 2004; 27: 2478-2484.

94 Wouters EF, Creutzberg EC, Schols AM. Systemic effects in COPD. Chest 2002; 121: 127S-130S.

95 Takabatake N, Nakamura H, Abe S, et al. The relationship between chronic hypoxemia and activation of the tumor necrosis factor-alpha system in patients with chronic obstructive pulmonary disease. Am J Respir Crit Care Med 2000; 161: 1179-1184.

96 Hotamisligil GS. The role of TNFalpha and TNF receptors in obesity and insulin resistance. J Intern Med 1999; 245: 621-625.

97 Rosen P, Nawroth PP, King G, Moller W, Tritschler HJ, Packer L. The role of oxidative stress in the onset and progression of diabetes and its complications. Diabetes Metab Res Rev 2001; 17: 189-212.

98 Smeeth L, Thomas SL, Hall AJ, Hubbard R, Farrington P, Vallance P. Risk of myocardial infarction and stroke after acute infection or vaccination. N Engl J Med 2004; 351: 2611-2618.

99 Pai JK, Pischon T, Ma J, et al. Inflammatory markers and the risk of coronary heart disease in men and women. N Engl J Med 2004; 351: 2599-2610.

100 Harvey MG, Hancox RJ. Elevation of cardiac troponins in exacerbation of chronic obstructive pulmonary disease. Emerg Med Australas 2004; 16: 212-215.

101 Ridker PM, Rifai N, Rose L, Buring JE, Cook NR. Comparison of C-reactive protein and low-density lipoprotein cholesterol levels in the prediction of first cardiovascular events. N Engl J Med 2002; 347: 1557-1565.

102 Celli BR, Cote CG, Marin JM, et al. The body-mass index, airflow obstruction, dyspnea, and exercise capacity index in chronic obstructive pulmonary disease. N Engl J Med 2004; 350: 1005-1012.

103 McCrory DC, Brown CD. Anti-cholinergic bronchodilators versus beta2-sympathomimetic agents for acute exacerbations of chronic obstructive pulmonary disease. Cochrane Database Syst Rev 2002; 4: CD003900.

104 Rennard SI. Treatment of stable chronic obstructive pulmonary disease. Lancet 2004; 364: 791-802.

105 Mahler DA, Donohue JF, Barbee RA, et al. Efficacy of salmeterol xinafoate in the treatment of COPD. Chest 1999; 115: 957-965.

106 Rennard SI, Anderson W, ZuWallack R, et al. Use of a long-acting inhaled $\beta 2$-adrenergic agonist, salmeterol xinafoate, in patients with chronic obstructive pulmonary disease. Am J Respir Crit Care Med 2001; 163: 1087-1092.

107 Vincken W, van Noord JA, Greefhorst AP, et al. Improved health outcomes in patients with COPD during $1 \mathrm{yr}^{\prime} \mathrm{s}$ treatment with tiotropium. Eur Respir J 2002; 19: 209-216.

108 Casaburi R, Mahler DA, Jones PW, et al. A long-term evaluation of once-daily inhaled tiotropium in chronic obstructive pulmonary disease. Eur Respir J 2002; 19: 217-224.

109 Niewoehner DE, Rice K, Cote C, et al. Prevention of exacerbations of chronic obstructive pulmonary disease with tiotropium, a once-daily inhaled anticholinergic bronchodilator: a randomized trial. Ann Intern Med 2005; 143: 317-326.

110 Appleton S, Poole P, Smith B, Veale A, Bara A. Longacting beta2-agonists for chronic obstructive pulmonary disease patients with poorly reversible airflow limitation. Cochrane Database Syst Rev 2002; 4: CD001104.

111 Johnson M, Rennard S. Alternative mechanisms for longacting $\beta 2$-adrenergic agonists in COPD. Chest 2001; 120: 258-270.

112 Buhling F, Lieder N, Reisenauer A, Welte T. Antiinflammatory effect of tiotropium mediated by suppression 
of acetylcholine-induced release of chemotactic activity. Eur Respir J 2004; 24: 318S.

113 Brightling CE, Monteiro W, Ward R, et al. Sputum eosinophilia and short-term response to prednisolone in chronic obstructive pulmonary disease: a randomised controlled trial. Lancet 2000; 356: 1480-1485.

114 Sin DD, Lacy P, York E, Man SF. Effects of fluticasone on systemic markers of inflammation in chronic obstructive pulmonary disease. Am J Respir Crit Care Med 2004; 170: 760-765.

115 Dentener MA, Creutzberg EC, Schols AM, et al. Systemic anti-inflammatory mediators in COPD: increase in soluble interleukin 1 receptor II during treatment of exacerbations. Thorax 2001; 56: 721-726.

116 Davies L, Angus RM, Calverley PM. Oral corticosteroids in patients admitted to hospital with exacerbations of chronic obstructive pulmonary disease: a prospective randomised controlled trial. Lancet 1999; 354: 456-460.

117 Sayiner A, Aytemur ZA, Cirit M, Unsal I. Systemic glucocorticoids in severe exacerbations of COPD. Chest 2001; 119: 726-730.

118 Niewoehner DE, Erbland ML, Deupree RH, et al. Effect of systemic glucocorticoids on exacerbations of chronic obstructive pulmonary disease. N Engl J Med 1999; 340: 1941-1947.

119 Aaron SD, Vandemheen KL, Hebert P, et al. Outpatient oral prednisone after emergency treatment of chronic obstructive pulmonary disease. $N$ Engl J Med 2003; 348: 2618-2625.

120 Maltais F, Ostinelli J, Bourbeau J, et al. Comparison of nebulized budesonide and oral prednisolone with placebo in the treatment of acute exacerbations of chronic obstructive pulmonary disease: a randomized controlled trial. Am J Respir Crit Care Med 2002; 165: 698-703.

121 Confalonieri M, Urbino R, Potena A, et al. Hydrocortisone infusion for severe community-acquired pneumonia: a preliminary randomized study. Am J Respir Crit Care Med 2005; 171: 242-248.

122 Pauwels RA, Lofdahl CG, Laitinen LA, et al. Long-term treatment with inhaled budesonide in persons with mild chronic obstructive pulmonary disease who continue smoking. N Engl J Med 1999; 340: 1948-1953.

123 Vestbo J, Sorensen T, Lange P, Brix A, Torre P, Viskum K. Long-term effect of inhaled budesonide in mild and moderate chronic obstructive pulmonary disease: a randomised controlled trial. Lancet 1999; 353: 1819-1823.

124 Lung Health Study Research Group. Effect of inhaled triamcinolone on the decline in pulmonary function in chronic obstructive pulmonary disease. $N$ Engl J Med 2000; 343: 1902-1909.

125 Szafranski W, Cukier A, Ramirez A, et al. Efficacy and safety of budesonide/formoterol in the management of chronic obstructive pulmonary disease. Eur Respir J 2003; 21: 74-81.

126 Calverley $\mathrm{P}$, Pauwels R, Vestbo J, et al. Combined salmeterol and fluticasone in the treatment of chronic obstructive pulmonary disease: a randomoised controlled trial. Lancet 2003; 361: 449-456.

127 Calverley PM, Boonsawat W, Cseke Z, Zhong N, Peterson S, Olsson H. Maintenance therapy with budesonide and formoterol in chronic obstructive pulmonary disease. Eur Respir J 2003; 22: 912-919.

128 Sin DD, Tu JV. Inhaled corticosteroids and the risk of mortality and readmission in elderly patients with chronic obstructive pulmonary disease. Am J Respir Crit Care Med 2001; 164: 580-584.

129 Sin DD, Wu L, Anderson JA, et al. Inhaled corticosteroids and mortality in chronic obstructive pulmonary disease. Thorax 2005; 60: 992-997.

130 Macie C, Wooldrage K, Manfreda J, Anthonisen NR. Inhaled corticosteroids and mortality in COPD. Chest 2006; 130: 640-646.

131 Calverley PM, Anderson JA, Celli B, et al. Salmeterol and fluticasone propionate and survival in chronic obstructive pulmonary disease. $N$ Engl J Med 2007; 356: 775-789.

132 Saint S, Bent S, Vittinghoff E, Grady D. Antibiotics in chronic obstructive pulmonary disease exacerbations. A meta-analysis. JAMA 1995; 273: 957-960.

133 Groenewegen KH, Wouters EF. Bacterial infections in patients requiring admission for an acute exacerbation of COPD; a 1-year prospective study. Respir Med 2003; 97: 770-777.

134 Ellis DA, Anderson IM, Stewart SM, Calder J, Crofton JW Exacerbations of chronic bronchitis: exogenous or endogenous infection? Br J Dis Chest 1978; 72: 115-121.

135 Wilson R, Jones P, Schaberg T, Arvis P, Duprat-Lomon I, Sagnier PP. Antibiotic treatment and factors influencing short and long term outcomes of acute exacerbations of chronic bronchitis. Thorax 2006; 61: 337-342.

136 Anthonisen NR, Manfreda J, Warren CP, Hershfield ES, Harding GK, Nelson NA. Antibiotic therapy in exacerbations of chronic obstructive pulmonary disease. Ann Intern Med 1987; 106: 196-204.

137 Wilson R, Allegra L, Huchon G, et al. Short-term and long-term outcomes of moxifloxacin compared to standard antibiotic treatment in acute exacerbations of chronic bronchitis. Chest 2004; 125: 953-964.

138 Lode H, Eller J, Linnhoff A, Ioanas M. Levofloxacin versus clarithromycin in COPD exacerbation: focus on exacerbation-free interval. Eur Respir J 2004; 24: 947-953.

139 Peng CC, Aspinall SL, Good CB, Atwood CW Jr, Chang CC. Equal effectiveness of older traditional antibiotics and newer broad-spectrum antibiotics in treating patients with acute exacerbations of chronic bronchitis. South Med J 2003; 96: 986-991.

140 Allegra L, Blasi F, de Bernardi B, Cosentini R, Tarsia P. Antibiotic treatment and baseline severity of disease in acute exacerbations of chronic bronchitis: a re-evaluation of previously published data of a placebo-controlled randomized study. Pulm Pharmacol Ther 2001; 14: 149-155.

141 Stockley RA, O'Brien C, Pye A, Hill SL. Relationship of sputum color to nature and outpatient management of acute exacerbations of COPD. Chest 2000; 117: 1638-1645.

142 Nouira S, Marghli S, Belghith M, Besbes L, Elatrous S, Abroug F. Once daily oral ofloxacin in chronic obstructive pulmonary disease exacerbation requiring mechanical ventilation: a randomised placebo-controlled trial. Lancet 2001; 358: 2020-2025.

143 Martinez FJ, Grossman RF, Zadeikis N, et al. Patient stratification in the management of acute bacterial 
exacerbation of chronic bronchitis: the role of levofloxacin 750 mg. Eur Respir J 2005; 25: 1001-1010.

144 Wilson R, Schentag JJ, Ball P, Mandell L. A comparison of gemifloxacin and clarithromycin in acute exacerbations of chronic bronchitis and long-term clinical outcomes. Clin Ther 2002; 24: 639-652.

145 Evans TW. International Consensus Conferences in Intensive Care Medicine: non-invasive positive pressure ventilation in acute respiratory failure. Organised jointly by the American Thoracic Society, the European Respiratory Society, the European Society of Intensive Care Medicine, and the Societe de Reanimation de Langue Francaise, and approved by the ATS Board of Directors, December 2000. Intensive Care Med 2001; 27: 166-178.

146 Lightowler JV, Wedzicha JA, Elliott MW, Ram FS. Noninvasive positive pressure ventilation to treat respiratory failure resulting from exacerbations of chronic obstructive pulmonary disease: Cochrane systematic review and meta-analysis. BMJ 2003; 326: 185.

147 Ram FS, Wellington S, Rowe BH, Wedzicha JA. Noninvasive positive pressure ventilation for treatment of respiratory failure due to severe acute exacerbations of asthma. Cochrane Database Syst Rev 2005; 7: CD004360.

148 Conti G, Antonelli M, Navalesi P, et al. Noninvasive vs. conventional mechanical ventilation in patients with chronic obstructive pulmonary disease after failure of medical treatment in the ward: a randomized trial. Intensive Care Med 2002; 28: 1701-1707.

149 Plant PK, Owen JL, Elliott MW. Non-invasive ventilation in acute exacerbations of chronic obstructive pulmonary disease: long term survival and predictors of in-hospital outcome. Thorax 2001; 56: 708-712.

150 Plant PK, Owen JL, Elliott MW. Early use of non-invasive ventilation for acute exacerbations of chronic obstructive pulmonary disease on general respiratory wards: a multicentre randomised controlled trial. Lancet 2000; 355: 1931-1935.

151 Plant PK, Owen JL, Parrott S, Elliott MW. Cost effectiveness of ward based non-invasive ventilation for acute exacerbations of chronic obstructive pulmonary disease: economic analysis of randomised controlled trial. BMJ 2003; 326: 956.

152 Barnes PJ, Hansel TT. Prospects for new drugs for chronic obstructive pulmonary disease. Lancet 2004; 364 985-996.

153 Lipworth BJ. Phosphodiesterase-4 inhibitors for asthma and chronic obstructive pulmonary disease. Lancet 2005; 365: 167-175.

154 Martorana PA, Beume R, Lucattelli M, Wollin L, Lungarella G. Roflumilast fully prevents emphysema in mice chronically exposed to cigarette smoke. Am J Respir Crit Care Med 2005; 172: 848-853.

155 Rabe KF, Bateman ED, O'Donnell D, Witte S, Bredenbroker D, Bethke TD. Roflumilast - an oral antiinflammatory treatment for chronic obstructive pulmonary disease: a randomised controlled trial. Lancet 2005; 366: 563-571.

156 Rennard SI, Schachter N, Strek M, Rickard K, Amit O. Cilomilast for COPD: results of a 6-month, placebocontrolled study of a potent, selective inhibitor of phosphodiesterase 4. Chest 2006; 129: 56-66.

157 Beeh KM, Kornmann O, Buhl R, Culpitt SV, Giembycz MA, Barnes PJ. Neutrophil chemotactic activity of sputum from patients with COPD: role of interleukin 8 and leukotriene B4. Chest 2003; 123: 1240-1247.

158 Widdowson KL, Elliott JD, Veber DF, et al. Evaluation of potent and selective small-molecule antagonists for the CXCR2 chemokine receptor. J Med Chem 2004; 47: 1319-1321.

159 Grandjean EM, Berthet P, Ruffmann R, Leuenberger P. Efficacy of oral long-term $\mathrm{N}$-acetylcysteine in chronic bronchopulmonary disease: a meta-analysis of published double-blind, placebo-controlled clinical trials. Clin Ther 2000; 22: 209-221.

160 Decramer M, Rutten-van Molken M, Dekhuijzen PN, et al. Effects of $\mathrm{N}$-acetylcysteine on outcomes in chronic obstructive pulmonary disease (Bronchitis Randomized on NAC Cost-Utility Study, BRONCUS): a randomised placebo-controlled trial. Lancet 2005; 365: 1552-1560.

161 Rodriguez-Roisin R. Toward a consensus definition for COPD exacerbations. Chest 2000; 117: 398S-401S. 